\title{
APPLICATION OF THE “JUMPING FROGS" ALGORITHM FOR RESEARCH AND OPTIMIZATION OF THE TECHNOLOGICAL PROCESS
}

Koshevoy N. D. - Dr. Sc., Professor, Head of the Department of Intelligent Measuring Systems and Quality Engineering, National Aerospace University named after N. Ye. Zhukovsky "Kharkiv aviation institute", Kharkiv, Ukraine.

Muratov V. V. - Postgraduate student of the department of intellectual measuring systems and quality engineering, National Aerospace University named after N. Ye. Zhukovsky "Kharkiv aviation institute", Kharkiv, Ukraine.

Kirichenko A. L. - PhD, Chief Technologist, State Enterprise "Research-industrial complex "Pavlograd Chemical Plant", Pavlograd, Ukraine.

Borisenko S. A. - Research Team Leader, State Enterprise "Research-industrial complex "Pavlograd Chemical Plant", Pavlograd, Ukraine.

\section{ABSTRACT}

Context. An application of the method of a "jumping frogs" search algorithm to construct optimal experiment plans for cost (time) in the study of technological processes and systems that allow the implementation of an active experiment on them is proposed.

The object of study are optimization methods for cost (time) costs of experimental designs, based on the application of a "jumping frogs" search algorithm.

Objective. To obtain optimization results by optimizing the search of a "jumping frogs" search algorithm for the cost (time) costs of plans for a full factorial experiment.

Method. A method is proposed for constructing a cost-effective (time) implementation of an experiment planning matrix using algorithms for searching for "jumping frogs". At the beginning, the number of factors and the cost of transitions for each factor level are entered. Then, taking into account the entered data, the initial experiment planning matrix is formed. Then, taking into account the entered data, the initial matrix of experiment planning is formed. The "jumping frogs" method determines the "successful frog" by the lowest cost of transitions between levels for each of the factors. After that, the permutations of the "frogs" are performed. The "frog" strives for the most "successful" and, provided it stays close, remains in the location. Then the gain is calculated in comparison with the initial cost (time) of the experiment.

Results. Software has been developed that implements the proposed method, which was used to conduct computational experiments to study the properties of these methods in the study of technological processes and systems that allow the implementation of an active experiment on them. The experimental designs that are optimal in terms of cost (time) are obtained, and the winnings in the optimization results are compared with the initial cost of the experiment. A comparative analysis of optimization methods for the cost (time) costs of plans for a full factorial experiment is carried out.

Conclusions. The conducted experiments confirmed the operability of the proposed method and the software that implements it, and also allows us to recommend it for practical use in constructing optimal experiment planning matrices.

KEYWORDS: optimal plan, jumping frogs search algorithm, optimization, experiment planning, cost, win.

\section{ABBREVIATIONS \\ MSRF is a mixed solid rocket fuel; \\ SRF is a solid rocket fuel.}

\section{NOMENCLATURE}

$k$ is a number of object factors introduced into the study;

$t$ is a program run time, $\mathrm{s}$

$B$ is a winnings;

$N$ is a number of experiments in the planning matrix of the experiment and the matrix of costs of transitions between the levels of factors;

$X_{i}$ is a levels of factors;

$C_{0}$ is a total cost of the experiment, conv. units;

$t_{0}$ is a total time of the experiment, $\mathrm{h}$;

$C_{i, j}$ is a cost of the transition from the $i$-th experience to the $j$-th, conventional units;

$t_{i, j}$ is a time of the transition from the $i$-th experience to the $j$-th, conventional units:

$C_{i}$ is a cost of the $i$-th factor of the studied process; $t_{i}$ is a time of the $i$-th factor of the studied process;

$b_{i, j}$ is an unknown coefficients of the mathematical model;

$Y_{i}$ is a process optimization criteria.

\section{INTRODUCTION}

The most important part of scientific studies are experiments. This is one of the main ways to get new scientific knowledge. The basis of this method is an experiment, representing a scientifically delivered experience or observation of the phenomenon under precisely taken into account conditions, allowing to monitor its progress, to control it, to recreate it every time when these conditions are repeated. From ordinary, passive observation, the experiment is distinguished by the active influence of the researcher on the phenomenon being studied. 
Planning an experiment is a section of mathematical statistics that studies methods for organizing a set of experiments with different conditions to obtain the most reliable information about the properties of the object under investigation in the presence of uncontrolled random perturbations. The use of experimental planning makes the experimenter's behavior purposeful and organized, significantly contributing to the increase of his labor productivity and the reliability of the results obtained. An important advantage of the method is its universality, suitability in the vast majority of areas of research.

The object of study is the technological processes and systems that allow the implementation of an active experiment on them.

The subject of study is the optimization method for cost (time) costs of experiment plans, based on the application of a "jumping frogs" search algorithm.

The purpose of the work is the development of a method and software for optimization of plans for a full factorial experiment using the search algorithm for "jumping frogs".

\section{PROBLEM STATEMENT}

Experimental research methods are widely used to optimize production processes. One of the main objectives of the experiment is to obtain the maximum amount of information about the influence of the factors studied on the production process. Further, a mathematical model of the object under investigation is constructed. At the same time, it is necessary to obtain models with minimal cost and time costs. This is especially important in the study of long and costly processes. The task of optimizing plans at a cost (time) of the experiment is NP-complete, i.e. for its solution takes time and a large number of computations, rapidly growing with increasing dimension of the problem. Therefore, a complete search of all possible solutions is difficult. In this connection it is necessary to find solutions using approximate algorithms.

The task of optimizing the design of experiments on cost costs is NP-complete, i.e. for its solution, it takes time and a large number of calculations, rapidly growing with increasing dimension of the problem. Therefore, a complete enumeration of all possible solutions is difficult. In this regard, it is necessary to find solutions using approximate algorithms, for example, such as an algorithm of optimization by a swarm of particles.

1. Total cost of the experiment:

$$
C_{0}=\sum_{i=1}^{k} C_{i}+\sum_{j=1}^{N} \sum_{i=1}^{k} C_{i j} \rightarrow \min .
$$

2. Total experiment time:

$$
t_{0}=\sum_{i=1}^{k} t_{i}+\sum_{j=1}^{N} \sum_{i=1}^{k} t_{i j} \rightarrow \min .
$$

\section{REVIEW OF THE LITERATURE}

Combinatorical optimization methods are known [3-8], but they are not used for constructing multivariate experiment plans that are optimal in cost and time costs. There are also known examples of constructing multifactorial design of an experiment described in, based on the use of the following optimization methods: analysis of permutations; sequential approximation method; branch and bound method; random search (permutation of rows of the planning matrix); simplex method; ant algorithm; genetic algorithm; annealing method; greedy algorithm; swarm of particles; jumping frogs [12]; monkey search [13]; search for a school of fish [16].

The effectiveness of the use of these methods is shown in the study of various technological processes, devices and systems. These methods have both advantages and disadvantages. For example, with a large number of factors, a complete search of all the rows of the experiment planning matrix requires a considerable length of time, while other methods make it possible to obtain an optimal experiment design for a limited number of factors $k$. With a large number of factors, the optimization results only approach the optimal experimental design. To solve the problem of constructing optimal experimental designs, it is advisable to use the "jumping frogs" method developed by the authors to compare optimization results. Based on this method, the technological process of manufacturing SRF was investigated and optimized.

All these methods have both advantages and disadvantages. For example, with a large number of factors, a lot of time is required for a complete search of all the rows of the planning matrix, and other algorithms allow obtaining an optimal experiment plan for a limited number of factors $k$. With a large number of factors, the optimization results are approximated to the optimal experiment plan. In view of this, it is advisable to use the search algorithm for "jumping frogs" by a school to compare the results. Optimization of experiment cost plans full (time) costs by exhaustive search at the current level of computing techniques can only be solved for the number of factors $k \leq 3$. Therefore, the problem of reduction many plans for a multivariate experiment with minimum number of transitions of factor levels to search for the optimal cost (time) the cost of its implementation.

There are methods based on the determination of the content of liquid-viscous components, the effect of products on the physicochemical properties of MSRF [3]. In well-known sources [4], mathematical models of the influence of the fractional composition of the SRF on the characteristics of MSRF are not given explicitly.

\section{MATERIALS AND METHODS}

A method and software for optimizing the plans for a full factorial experiment on cost (time) costs using the search algorithm for a "jumping frogs" has been developed. The essence of the application of the search algorithm for "jumping frogs" is as follows: 
Step 1. At the beginning of the work, the number of factors $\mathrm{k}$ is introduced.

Step 2. Enter the cost of transitions between levels for each of the factors.

Step 3. Depending on the selected number of factors, an experiment planning matrix is constructed.

Step 4. Calculation of the initial cost of the experiment.

Step 5. Generation of the cost matrix of transitions between levels for each of the factors.

Step 6. Sorting the indices and generating an array of indices for the cost of transitions between levels for each of the factors.

Step 7. Rearrangements in the columns in accordance with the array of indices for the cost of transitions between levels for each of the factors.

Step 8. Enumerating between all blocks of columns ("memeplexes" in which the "frog" moves).

Step 9. Determining the starting point for further enumeration, based on the least sum of the cost of transitions between levels for each of the factors.

Step 10. Performing a search within the column block in which the "frog" is located by the minimum value of the sum of the costs of transitions between levels for each of the factors.

Step 11. Go to the next row of the planning matrix and compare with the previous one. A search is performed in the column block with the lowest value of the sum of the costs of transitions between levels and the establishment of the corresponding block (interchanging in the planning matrix of the experiment).

Step 12. Construction of an optimal experiment planning matrix.

Step 13. Calculation of the total cost of the experiment.

Step 14. The calculation of the magnitude of the gain $B$ as the ratio of the initial cost of the $C_{\text {init }}$ experiment to the cost of implementing the optimal planning matrix of the experiment $C_{\text {opt }}$.

$$
B=\frac{C_{\text {init }}}{C_{\text {opt }}} .
$$

Step 15. Calculation of the time t spent on optimizing the design of the full factorial experiment using the "jumping frogs" method.

\section{EXPERIMENTS}

Practical experiments implemented in this article were carried out as part of the study of the technological process of manufacturing solid rocket fuel (hereinafter referred as SRF). Existing types of mixed solid rocket fuel (hereinafter referred as MSRF) have a specific impulse of $\leq 250 \mathrm{~s}$, with an average pressure in the combustion chamber $p_{\mathrm{k}}=70-100 \mathrm{~atm}$. and the degree of expansion of the nozzle (the ratio of the nozzle exit crosssectional area to the critical nozzle cross-sectional area, hereinafter referred to as $\left.\mathrm{S}_{\mathrm{a}} / \mathrm{S}_{\mathrm{kr}}\right) \mathrm{S}_{\mathrm{a}} / \mathrm{S}_{\mathrm{kr}} \leq 10$, however, the modern space-rocket industry requires the creation of MSRF recipes with an increased impulse of $\geq 265 \mathrm{~s}$.

The work presented in this article was performed to optimize the formulation with a thermodynamic estimation of parameters, which consists in finding the optimal formulation of solid rocket fuel with optimization criteria: specific impulse, fuel density.

The following components were used to model the formulation: product 28 , aluminium powder A-4, product 14 and binders based on modified rubber of the type with technological additives. The use of such substances in the manufacture of SRF allows you to create formulations with a high level of energy and acceptable performance characteristics at the stages of manufacturing SRF, product operation, etc. It is also necessary to measure the pressure in the combustion chamber of the engine.

The binder content is taken in the amount of $11 \%$, since the results of laboratory studies have shown that such a quantity of binder is necessary to achieve the required rheological characteristics of the mixture in the manufacture of SRF. However, the use of modern substances in the manufacture of binders for SRF allows to increase the degree of filling of SRF with solid substances, due to a decrease in the content of liquid-viscous components to $10 \% \rightarrow 9 \% \rightarrow 8 \%$, which theoretically allows us to expect an increase in specific impulse by $1 \% \rightarrow 2 \% \rightarrow 3 \%$. In this case, it is necessary to monitor performance at an acceptable level. Since the basic formulation has a relatively low oxygen balance, an equivalent increase in the degree of SRF filling with solids, due to a decrease in liquid-viscous components, should be performed in favor of an oxidizing agent (product 28).

We take energy components in such quantity:

- product $28-35 \%-70 \%$;

- aluminum A-4 - 9\% - 44\%;

- product $14-10 \%-45 \%$.

The range of variation of energy components is $35 \%$, which is necessary for the formation of experimental plans and allows you to cover a wide range of SRF recipes. The approach used to optimize the prescription composition of SRF is based on the construction of optimal experimental plans and allows one to determine with high accuracy the optimal composition of SRF according to optimization criteria.

The experimental design was optimized using this method. A full factorial experiment was conducted to study the formulation with thermodynamic evaluation of the parameters, on the basis of which recommendations were made regarding the influence of the formulation on the energy characteristics of the rocket engine and component content. Mathematical models are constructed, the coefficients of which characterize the influence of the recipe content on acceptable operational characteristics at the stages of manufacturing SRF.

We determine the factors by which it is possible to act on the optimized object. The choice of factors is a very crucial step in preparing for the planning of an experiment, the success of optimization depends on 
their successful choice. Factors affecting the energy characteristics of the MSRF were selected: $X_{1}$ is the content of the product 28 component; $\mathrm{X}_{2}$ is the content of the aluminium component $\mathrm{A}-4 ; \mathrm{X}_{3}$ is the content of component product 14 .

The polynomial model of the process under study, which we will use at the first stage of the planning of the experiment, is an incomplete quadratic function:

$$
\begin{gathered}
Y=b_{0}+b_{1} X_{1}+b_{2} X_{2}+b_{3} X_{3}+b_{12} X_{1} X_{2}+b_{13} X_{1} X_{3}+ \\
+b_{23} X_{2} X_{3}+b_{123} X_{1} X_{2} X_{3}
\end{gathered}
$$

where $b_{0}, b_{1}, b_{2}, b_{12}, b_{13}, b_{23}, b_{123}$ are the unknown coefficients of the mathematical model.

The first stage of planning an experiment to obtain a mathematical model is based on varying factors at two levels: "+1" - the upper limit of the range of component content; "-1" is the lower limit of the range of component content. The process optimization criteria are as follows: $\mathrm{Y}_{1}$ - specific impulse, $\mathrm{s} ; \mathrm{Y}_{2}-$ density, $\mathrm{kg} / \mathrm{m}^{3}$. Based on the results of the experiment, we will find the values of the unknown coefficients of the model and the optimal ratios of the components. The planning matrix of the initial experiment is given in table 1 .

Table 1 - Initial experiment planning matrix

\begin{tabular}{|c|c|c|c|}
\hline \multicolumn{4}{|c|}{ Initial plan } \\
\hline \multirow{2}{*}{$\begin{array}{c}\text { Experience } \\
\text { number }\end{array}$} & \multicolumn{3}{|c|}{ Destination of factors } \\
\cline { 2 - 4 } & $\mathrm{X}_{1}$ & $\mathrm{X}_{2}$ & $\mathrm{X}_{3}$ \\
\hline 1 & -1 & -1 & -1 \\
\hline 2 & +1 & -1 & -1 \\
\hline 3 & -1 & +1 & -1 \\
\hline 4 & +1 & +1 & -1 \\
\hline 5 & -1 & -1 & +1 \\
\hline 6 & +1 & -1 & +1 \\
\hline 7 & -1 & +1 & +1 \\
\hline 8 & +1 & +1 & +1 \\
\hline
\end{tabular}

The costs of changing the values of factor levels in the study of energy components by specific impulse are given in table 2. The natural values of the levels of factors in the study of energy components depending on the content of the binder components are given in table 3. The cost of changing the values of factor levels in the study of energy components by fuel density are given in table 4 .

Table 2 - Costs of changing factor level values in the study of energy components by specific impulse

\begin{tabular}{|c|c|c|c|c|c|c|c|c|c|c|c|c|}
\hline $\begin{array}{c}\text { Cost of } \\
\text { chan- } \\
\text { ging va- } \\
\text { lues of } \\
\text { factor } \\
\text { levels, } \\
\text { conv. } \\
\text { units }\end{array}$ & $\begin{array}{c}\text { The content of } \\
\text { the binder com- } \\
\text { ponents } 11 \%\end{array}$ & \multicolumn{1}{|c|}{$\begin{array}{c}\text { The content of } \\
\text { the binder com- } \\
\text { ponents } 10 \%\end{array}$} & \multicolumn{2}{|c|}{$\begin{array}{c}\text { The content of } \\
\text { the binder com- } \\
\text { ponents } 9 \%\end{array}$} & \multicolumn{2}{|c|}{$\begin{array}{c}\text { The content of } \\
\text { the binder com- } \\
\text { ponents } 9 \%\end{array}$} \\
\hline $\begin{array}{c}\text { from } \\
\text { "-1" } \\
\text { to "+1" }\end{array}$ & 15.8 & 10.5 & 11.5 & 16.5 & 10.5 & 11.5 & 16.8 & 10.5 & 11.5 & 17.2 & 10.5 & 11.5 \\
\hline $\begin{array}{c}\text { from } \\
\text { "+1" } \\
\text { to "-1" }\end{array}$ & 27.0 & 32.5 & 33.5 & 27.4 & 32.5 & 33.5 & 28.0 & 32.5 & 33.5 & 33.6 & 32.5 & 33.5 \\
\hline
\end{tabular}

(C) Koshevoy N. D., Muratov V. V., Kirichenko A. L., Borisenko S. A., 2021 DOI $10.15588 / 1607-3274-2021-1-6$
Table 3 - Natural values of factor levels in the study of

\begin{tabular}{|c|c|c|c|}
\hline \multirow{4}{*}{ Factor levels } & \multicolumn{3}{|c|}{ Destination of factors } \\
\hline & \multicolumn{3}{|c|}{ The content of the binder components $11 \%$} \\
\hline & $\mathrm{X}_{1}$ & \begin{tabular}{|l|l}
$\mathrm{X}_{2}$ \\
\end{tabular} & $\mathrm{X}_{3}$ \\
\hline & Product $28, \%$ & Aluminium A-4, \% & Product $14, \%$ \\
\hline "-1" & 35 & 9 & 10 \\
\hline "+1" & 70 & 44 & 45 \\
\hline \multirow{4}{*}{ Factor levels } & & Destination of factor & \\
\hline & \multicolumn{3}{|c|}{ The content of the binder components $10 \%$} \\
\hline & $\mathrm{X}_{1}$ & $\mathrm{X}_{2}$ & $\mathrm{X}_{3}$ \\
\hline & Product $28, \%$ & Aluminium A-4, \% & Product $14, \%$ \\
\hline$"-1 "$ & 36 & 9 & 10 \\
\hline$+1 "$ & 71 & 44 & 45 \\
\hline \multirow{4}{*}{ Factor levels } & & Destination of factor & \\
\hline & \multicolumn{3}{|c|}{ The content of the binder components $9 \%$} \\
\hline & $\mathrm{X}_{1}$ & $\mathrm{X}_{2}$ & $\mathrm{X}_{3}$ \\
\hline & Product $28, \%$ & Aluminium A-4, \% & Product $14, \%$ \\
\hline "-1" & 37 & 9 & 10 \\
\hline " $+1 "$ & 72 & 44 & 45 \\
\hline \multirow{4}{*}{ Factor levels } & & Destination of factor & \\
\hline & \multicolumn{3}{|c|}{ The content of the binder components $8 \%$} \\
\hline & $\mathrm{X}_{1}$ & \begin{tabular}{|l|}
$X_{2}$ \\
\end{tabular} & $\mathrm{X}_{3}$ \\
\hline & Product $28, \%$ & Aluminium A-4, \% & Product $14, \%$ \\
\hline "-1" & 38 & 9 & 10 \\
\hline "+1" & 73 & 44 & 45 \\
\hline
\end{tabular}
energy components

Table 4 - Costs of changing factor level values in the study of

\begin{tabular}{|c|c|c|c|c|c|c|c|c|c|c|c|c|}
\hline \multirow{3}{*}{$\begin{array}{c}\text { Cost of } \\
\text { chan- } \\
\text { ging va- } \\
\text { lues of } \\
\text { factor } \\
\text { levels, } \\
\text { conv. } \\
\text { units }\end{array}$} & \multicolumn{12}{|c|}{ Designation of factors } \\
\hline & \multicolumn{3}{|c|}{$\begin{array}{c}\text { The content of } \\
\text { the binder } \\
\text { components } \\
11 \%\end{array}$} & \multicolumn{3}{|c|}{$\begin{array}{l}\text { The content of } \\
\text { the binder com- } \\
\text { ponents } 10 \%\end{array}$} & \multicolumn{3}{|c|}{$\begin{array}{l}\text { The content of } \\
\text { the binder } \\
\text { components } 9 \%\end{array}$} & \multicolumn{3}{|c|}{$\begin{array}{c}\text { The content of } \\
\text { the binder com- } \\
\text { ponents } 9 \%\end{array}$} \\
\hline & $\mathrm{X}_{1}$ & $\mathrm{X}_{2}$ & $X_{3}$ & $\mathrm{X}_{1}$ & $\mathrm{X}_{2}$ & $X_{3}$ & $\mathrm{X}_{1}$ & $X_{2}$ & $X_{3}$ & $X_{1}$ & $\mathrm{X}_{2}$ & $X_{3}$ \\
\hline $\begin{array}{l}\text { from } \\
\text { "- } 1 " \\
\text { to }+1\end{array}$ & 13.8 & 9.5 & 10.5 & 14.5 & 9.5 & 10.5 & 14.8 & 9.5 & 10.5 & 15.2 & 9.5 & 10.5 \\
\hline $\begin{array}{l}\text { from } \\
\text { " }+1 " \\
\text { to "-1" }\end{array}$ & 25.5 & 31.5 & 32.0 & 24.8 & 31.5 & 32.0 & 26.0 & 31.5 & 32.0 & 31.5 & 31.5 & 32.0 \\
\hline
\end{tabular}
energy components by fuel density

\section{RESULTS}

A method and a program have been developed optimization of plans for a full factorial experiment using the search algorithm for a "jumping frogs". Their operability and efficiency on some examples of research of systems and technological processes are proved.

The search for the optimal or close to the optimal plan obtained by this method is realized in a short time of the account. It is shown that in order to optimize the plans for a full factorial experiment, it is expedient to use the method of searching for a "jumping frogs" by research in objects with the number of factors $2 \leq k \leq 4$.

The optimal experimental design and research results are given in tables $5-8$.

The optimal experimental design and research results for the content of the binder components of $11 \%$ are presented in table 5.

For the costs of changing factor levels in the study of energy characteristics by specific impulse, presented in table 2, the optimization results are shown in table 5. The initial cost of the experiment is 515 conv. units The gain and cost of implementing the optimal experimental design obtained as a result of optimization using the "jumping frogs" method are shown in table 10. 
e-ISSN 1607-3274 Радіоелектроніка, інформатика, управління. 2021. № 1 p-ISSN 2313-688X Radio Electronics, Computer Science, Control. 2021. № 1

Table 5 - Optimal experimental design and research results (binder content 11\%)

\begin{tabular}{|c|c|c|c|c|c|c|c|c|c|}
\hline \multicolumn{5}{|c|}{ Specific impulse } & \multicolumn{5}{|c|}{ Density } \\
\hline \multirow{2}{*}{$\begin{array}{l}\text { Expe- } \\
\text { rience } \\
\text { number }\end{array}$} & \multicolumn{3}{|c|}{$\begin{array}{l}\text { Designation of } \\
\text { factors }\end{array}$} & \multirow[b]{2}{*}{$\mathrm{Y}_{1}$} & \multirow{2}{*}{$\begin{array}{l}\text { Experi- } \\
\text { ence } \\
\text { number }\end{array}$} & \multicolumn{3}{|c|}{$\begin{array}{l}\text { Designation of } \\
\text { factors }\end{array}$} & \multirow[b]{2}{*}{$\mathrm{Y}_{2}$} \\
\hline & $\mathrm{X}_{1}$ & $\mathrm{X}_{2}$ & $\mathrm{X}_{3}$ & & & $\mathrm{X}_{1}$ & $\mathrm{X}_{2}$ & $\mathrm{X}_{3}$ & \\
\hline 1 & +1 & -1 & -1 & 260.65 & 1 & +1 & -1 & -1 & 1.76 \\
\hline 2 & +1 & -1 & +1 & 218.03 & 2 & -1 & +1 & -1 & 1.94 \\
\hline 3 & +1 & +1 & +1 & 260.73 & 3 & +1 & +1 & -1 & 1.70 \\
\hline 4 & +1 & +1 & -1 & 257.66 & 4 & -1 & -1 & +1 & 1.85 \\
\hline 5 & -1 & +1 & -1 & 261.37 & 5 & +1 & -1 & +1 & 1.73 \\
\hline 6 & -1 & +1 & +1 & 249.26 & 6 & -1 & +1 & +1 & 1.81 \\
\hline 7 & -1 & -1 & +1 & 264.68 & 7 & -1 & -1 & -1 & 1.80 \\
\hline 8 & -1 & -1 & -1 & 261.20 & 8 & +1 & +1 & +1 & 1.75 \\
\hline
\end{tabular}

The optimal experimental design and research results for the content of binding components of $10 \%$ are presented in table 6 .

For the costs of changing factor levels in the study of energy characteristics by specific impulse, presented in table 2 , the optimization results are shown in table 6 . The initial cost of the experiment is 548 conv. units The gain and cost of implementing the optimal experimental design obtained as a result of optimization using the "jumping frogs" method are shown in table 10 .

Table 6 - Optimal experimental design and research results (binder content $10 \%$ )

\begin{tabular}{|c|c|c|c|c|c|c|c|c|c|}
\hline \multicolumn{5}{|c|}{ Specific impulse } & \multicolumn{5}{|c|}{ Density } \\
\hline \multirow{2}{*}{$\begin{array}{l}\text { Experi- } \\
\text { ence } \\
\text { number }\end{array}$} & \multicolumn{3}{|c|}{$\begin{array}{c}\text { Designation of } \\
\text { factors }\end{array}$} & \multirow[b]{2}{*}{$\mathrm{Y}_{1}$} & \multirow{2}{*}{$\begin{array}{c}\text { Experi- } \\
\text { ence } \\
\text { number }\end{array}$} & \multicolumn{3}{|c|}{$\begin{array}{l}\text { Designation of } \\
\text { factors }\end{array}$} & \\
\hline & $\mathrm{X}_{1}$ & $\mathrm{X}_{2}$ & $\mathrm{X}_{3}$ & & & $\mathrm{X}_{1}$ & $\mathrm{X}_{2}$ & $\mathrm{X}_{3}$ & $\mathrm{Y}_{2}$ \\
\hline 1 & -1 & +1 & -1 & 267.88 & 1 & -1 & +1 & -1 & 1.79 \\
\hline 2 & -1 & +1 & +1 & 225.87 & 2 & +1 & -1 & -1 & 1.93 \\
\hline 3 & +1 & +1 & +1 & 268.34 & 3 & +1 & +1 & -1 & 1.83 \\
\hline 4 & +1 & +1 & -1 & 267.44 & 4 & -1 & -1 & +1 & 1.77 \\
\hline 5 & +1 & -1 & -1 & 268.84 & 5 & -1 & +1 & +1 & 1.72 \\
\hline 6 & +1 & -1 & +1 & 258.84 & 6 & +1 & -1 & +1 & 1.91 \\
\hline 7 & -1 & -1 & +1 & 271.85 & 7 & -1 & -1 & -1 & 1.76 \\
\hline 8 & -1 & -1 & -1 & 268.57 & 8 & +1 & +1 & +1 & 1.72 \\
\hline
\end{tabular}

The optimal experimental design and research results for the content of the binder components of $9 \%$ are presented in table 7 .

For the costs of changing factor levels in the study of energy characteristics by specific impulse, presented in table 2 , the optimization results are shown in table 7 . In this case, the initial cost of the experiment is 570 conv. units The gain and cost of implementing the optimal experimental design obtained as a result of optimization using the "jumping frogs" method are shown in table 10.

The optimal experimental design and research results for the content of the binder components of $8 \%$ are presented in table 8 .

Table 7 - Optimal experimental design and research results (binder content $9 \%$ )

\begin{tabular}{|c|c|c|c|c|c|c|c|c|c|}
\hline \multicolumn{5}{|c|}{ Specific impulse } & \multicolumn{5}{|c|}{ Density } \\
\hline \multirow{2}{*}{$\begin{array}{l}\text { Experi- } \\
\text { ence } \\
\text { number }\end{array}$} & \multicolumn{3}{|c|}{$\begin{array}{l}\text { Designation of } \\
\text { factors }\end{array}$} & \multirow[b]{2}{*}{$\mathrm{Y}_{1}$} & \multirow{2}{*}{$\begin{array}{c}\text { Experi- } \\
\text { ence } \\
\text { number }\end{array}$} & \multicolumn{3}{|c|}{$\begin{array}{l}\text { Designation of } \\
\text { factors }\end{array}$} & \multirow[b]{2}{*}{$\mathrm{Y}_{2}$} \\
\hline & $\mathrm{X}_{1}$ & $\mathrm{X}_{2}$ & $\mathrm{X}_{3}$ & & & $\mathrm{X}_{1}$ & $\mathrm{X}_{2}$ & $\mathrm{X}_{3}$ & \\
\hline 1 & -1 & -1 & +1 & 268.14 & 1 & -1 & -1 & +1 & 1.72 \\
\hline 2 & +1 & -1 & +1 & 227.63 & 2 & -1 & +1 & -1 & 1.93 \\
\hline 3 & +1 & +1 & +1 & 269.99 & 3 & -1 & +1 & +1 & 1.75 \\
\hline 4 & -1 & +1 & +1 & 269.22 & 4 & +1 & -1 & -1 & 1.73 \\
\hline 5 & -1 & +1 & -1 & 269.89 & 5 & +1 & -1 & +1 & 1.72 \\
\hline 6 & +1 & +1 & -1 & 262.12 & 6 & +1 & +1 & -1 & 1.73 \\
\hline 7 & +1 & -1 & -1 & 271.83 & 7 & -1 & -1 & -1 & 1.76 \\
\hline 8 & -1 & -1 & -1 & 269.26 & 8 & +1 & +1 & +1 & 1.72 \\
\hline
\end{tabular}

(C) Koshevoy N. D., Muratov V. V., Kirichenko A. L., Borisenko S. A., 2021 DOI 10.15588/1607-3274-2021-1-6
For the costs of changing factor levels in the study of energy characteristics by specific impulse, presented in table 2 , the optimization results are shown in table 8 . In this case, the initial cost of the experiment is 610 conv. units. The gain and cost of implementing the optimal experimental design obtained as a result of optimization using the "jumping frogs" method are shown in table 10.

Table 8 - Optimal experimental design and research results (binder content $8 \%$ )

\begin{tabular}{|c|c|c|c|c|c|c|c|c|c|}
\hline \multicolumn{5}{|c|}{ Specific impulse } & \multicolumn{5}{|c|}{ Density } \\
\hline \multirow{2}{*}{$\begin{array}{c}\text { Experi- } \\
\text { ence } \\
\text { number }\end{array}$} & \multicolumn{3}{|c|}{$\begin{array}{c}\text { Designation of } \\
\text { factors }\end{array}$} & \multirow[b]{2}{*}{$\mathrm{Y}_{1}$} & \multirow{2}{*}{$\begin{array}{c}\text { Experi- } \\
\text { ence } \\
\text { number }\end{array}$} & \multicolumn{3}{|c|}{$\begin{array}{l}\text { Designation of } \\
\text { factors }\end{array}$} & \multirow[b]{2}{*}{$\mathrm{Y}_{2}$} \\
\hline & $\mathrm{X}_{1}$ & $\mathrm{X}_{2}$ & $\mathrm{X}_{3}$ & & & $\mathrm{X}_{1}$ & $\mathrm{X}_{2}$ & $\mathrm{X}_{3}$ & \\
\hline 1 & -1 & +1 & -1 & 267.90 & 1 & +1 & -1 & -1 & 1.72 \\
\hline 2 & -1 & +1 & +1 & 228.75 & 2 & -1 & -1 & +1 & 1.93 \\
\hline 3 & +1 & +1 & +1 & 271.45 & 3 & +1 & -1 & +1 & 1.75 \\
\hline 4 & +1 & +1 & -1 & 269.71 & 4 & -1 & +1 & -1 & 1.75 \\
\hline 5 & +1 & -1 & -1 & 270.64 & 5 & +1 & +1 & -1 & 1.76 \\
\hline 6 & +1 & -1 & +1 & 265.79 & 6 & -1 & +1 & +1 & 1.70 \\
\hline 7 & -1 & -1 & +1 & 271.50 & 7 & -1 & -1 & -1 & 1.75 \\
\hline 8 & -1 & -1 & -1 & 269.58 & 8 & +1 & +1 & +1 & 1.73 \\
\hline
\end{tabular}

The experiments carried out confirmed the efficiency of the "jumping frogs" method. The coefficients of mathematical models and the optimal ratio of components are given in table 9. They indicate the influence of factors on optimization criteria.

\section{DISCUSSION}

When studying the energy characteristics of fuel density, the cost of changing factor levels is presented in table 4, and the obtained optimization results are shown in table 5. The initial cost of the experiment is 475 conv. units The gain and cost of implementing the optimal experimental design obtained as a result of optimization using the "jumping frogs" method are shown in table 10.

When studying the energy characteristics of fuel density, the cost of changing factor levels is presented in table 4 , and the obtained optimization results are shown in table 6. The initial cost of the experiment is 500 conv. units The gain and cost of implementing the optimal experimental design obtained as a result of optimization using the "jumping frogs" method are shown in table 10.

When studying the energy characteristics of fuel density, the cost of changing factor levels is presented in table 4, and the obtained optimization results are shown in table 7. The initial cost of the experiment is 526 conv. units. The gain and cost of implementing the optimal experimental design obtained as a result of optimization using the "jumping frogs" method are shown in table 10.

When studying the energy characteristics of fuel density, the cost of changing factor levels is presented in table 4, and the obtained optimization results are shown in table 8. The initial cost of the experiment is 552 conv. units. The gain and cost of implementing the optimal experimental design obtained as a result of optimization using the "jumping frogs" method are shown in table 10. 
Table 9 - Mathematical models and optimal component ratios \begin{tabular}{|l|l|l}
\hline Criterion & Mathematical model coefficients & Optimal ratios
\end{tabular} \begin{tabular}{l|l|l} 
optimization & Mathematical model coefficients & $\begin{array}{c}\text { Optimal ratios } \\
\text { components }\end{array}$ \\
\hline
\end{tabular}

The content of the binder components $11 \%$

\begin{tabular}{|c|c|c|}
\hline \multirow{3}{*}{ Specific } & $b_{0}=90.625 ; b_{1}=13.125 ;$ & \\
impulse & $b_{2}=8.125 ; b_{3}=-0.125 ;$ & \\
& $b_{12}=7.375 ; b_{13}=8.375 ;$ & Product-28 $=49 \%$ \\
& $b_{23}=-10.625 ; b_{123}=6.125$ & Aluminium A-4 $=$ \\
& $b_{0}=50.625 ; b_{1}=5.25 ;$ & $18 \%$ \\
Density & $b_{2}=6.15 ; b_{3}=-0.75 ;$ & Product-14 $=22 \%$ \\
& $b_{12}=0.37 ; b_{13}=2.375 ;$ & \\
& $b_{23}=-0.65 ; b_{123}=0.5$ & \\
\hline
\end{tabular}

The content of the binder components $10 \%$

\begin{tabular}{|c|c|c|}
\hline \multirow{3}{*}{ Specific } & $b_{0}=100.65 ; b_{1}=18.12 ;$ & \\
impulse & $b_{2}=10.15 ; b_{3}=-0.15 ;$ & \\
& $b_{12}=9.375 ; b_{13}=11.35 ;$ & Product- $28=50 \%$ \\
& $b_{23}=-8.25 ; b_{123}=7.5$ & Aluminium A-4 $=$ \\
& & $18 \%$ \\
& $b_{0}=60.625 ; b_{1}=8.25 ;$ & Product- $14=22 \%$ \\
Density & $b_{2}=7.15 ; b_{3}=-0.25 ;$ & \\
& $b_{12}=0.75 ; b_{13}=3.75 ;$ & \\
& $b_{23}=-0.25 ; b_{123}=0.95$ & \\
& & \\
\end{tabular}

The content of the binder components $9 \%$

\begin{tabular}{|c|c|c|}
\hline \multirow{3}{*}{ Specific } & $b_{0}=115.65 ; b_{1}=22.12 ;$ & \\
impulse & $b_{2}=14.15 ; b_{3}=-0.1 ;$ & \\
& $b_{12}=11.75 ; b_{13}=14.5 ;$ & Product- $28=45 \%$ \\
& $b_{23}=-6.5 ; b_{123}=9.75$ & Aluminium A-4 $=$ \\
\hline & $b_{0}=70.625 ; b_{1}=9.5 ;$ & $16 \%$ \\
Density & $b_{2}=8.65 ; b_{3}=-0.2 ;$ & Product- $14=30 \%$ \\
& $b_{12}=0.925 ; b_{13}=4.65 ;$ & \\
& $b_{23}=-0.2 ; b_{123}=1.75$ & \\
\hline
\end{tabular}

The content of the binder components $8 \%$

\begin{tabular}{|c|c|c|}
\hline \multirow{3}{*}{ Specific } & $b_{0}=125.85 ; \mathrm{b}_{1}=25.70 ;$ & \\
impulse & $b_{2}=16.45 ; \mathrm{b}_{3}=-0.04 ;$ & \\
& $b_{12}=15.25 ; \mathrm{b}_{13}=17.125 ;$ & Product-28=44\% \\
& $b_{23}=-3.25 ; \mathrm{b}_{123}=11.675$. & Aluminium A-4 $=$ \\
\hline & $b_{0}=80.25 ; b_{1}=10.275 ;$ & $19 \%$ \\
Density & $b_{2}=9.125 ; b_{3}=-0.125 ;$ & Product-14=29\% \\
& $b_{12}=1.625 ; b_{13}=5.785 ;$ & \\
& $b_{23}=-0.135 ; b_{123}=2.95$ & \\
\hline
\end{tabular}

Table 10 - The results of the optimization of the experimental plans in the study of the energy characteristics of the prescription composition

\begin{tabular}{|c|c|c|c|c|}
\hline $\begin{array}{c}\text { Criterion } \\
\text { optimiza- } \\
\text { tion }\end{array}$ & $\begin{array}{c}\text { Cost of sales } \\
\text { experiment, } \\
\text { conv. units }\end{array}$ & $\begin{array}{c}\text { Cost of sales } \\
\text { optimal plan, } \\
\text { conv. units }\end{array}$ & Win & $\begin{array}{c}\text { Program } \\
\text { account time, } \mathrm{s}\end{array}$ \\
\hline \multicolumn{5}{|c|}{ The content of the binder components 11\% } \\
\hline $\begin{array}{c}\text { Specific } \\
\text { impulse }\end{array}$ & 515 & 198 & 2.60 & 0.02 \\
\hline Density & 475 & 196 & 2.42 & 0.01 \\
\hline \multicolumn{5}{|c|}{ The content of the binder components 10\% } \\
\hline $\begin{array}{l}\text { Specific } \\
\text { impulse }\end{array}$ & 548 & 210 & 2.41 & 0.01 \\
\hline Density & 500 & 200 & 2.53 & 0.01 \\
\hline \multicolumn{5}{|c|}{ The content of the binder components 9\% } \\
\hline $\begin{array}{l}\text { Specific } \\
\text { impulse }\end{array}$ & 570 & 218 & 2.62 & 0.01 \\
\hline Density & 526 & 198 & 2.67 & 0.01 \\
\hline \multicolumn{5}{|c|}{ The content of the binder components $8 \%$} \\
\hline $\begin{array}{l}\text { Specific } \\
\text { impulse }\end{array}$ & 610 & 226 & 2.72 & 0.02 \\
\hline Density & 552 & 208 & 2.65 & 0.02 \\
\hline
\end{tabular}

(C) Koshevoy N. D., Muratov V. V., Kirichenko A. L., Borisenko S. A., 2021 DOI 10.15588/1607-3274-2021-1-6

\section{CONCLUSIONS}

In this work, the urgent task of developing a prescription composition with a thermodynamic assessment of the parameters and manufacturing technology of MSRF, obtaining a sequence of experiments during the experiment, optimized by the method of "jumping frogs", ensuring the minimum cost of its implementation, is solved.

A method and software have been developed that implement the optimization of multifactorial design of experiments using the "jumping frogs" algorithm. The experiment plans that are optimal in terms of implementation cost are obtained, and also the winnings in the optimization results are shown compared to the initial cost of the experiment. The workability and effectiveness of the proposed method are proved by the examples of the study of the recipe composition with the thermodynamic estimation of parameters according to the energy characteristics of solid mixed rocket fuel. The study showed that the search for an optimal or close to the optimal design of the experiment using the method of "jumping frogs" gave good results. The gains obtained as a result of optimization using this method are significant. The application of the developed method and software based on the use of the "jumping frogs" algorithm is effective for a number of factors $k \geq 3$, since this method significantly reduces the number of permutations of the experiment planning matrix.

Taking into account the results of the study (table 10), when optimizing the cost of specific impulse and fuel density using the obtained coefficients of mathematical models, we can draw the following conclusions on the optimal ratios of the components of the MSRF:

- for the content of the binder components 11\%: the content of the components should correspond to: product- $28-49 \%$, A- $4-18 \%$, product- $14-22 \%$;

- for the content of the binder components $10 \%$ : the content of the components should correspond to: product- $28-50 \%$, A- $4-18 \%$, product- $14-22 \%$;

- for the content of the binder components $9 \%$ : the content of the components should correspond to: product- $28-45 \%$, A- $4-16 \%$, product- $14-30 \%$;

- for the content of the binder components $8 \%$ : the content of the components should correspond to: product- $28-44 \%$, A-4 - 19\%, product- $14-29 \%$.

It should be noted that with an increase in the average pressure in the combustion chamber of the engine, it is advisable to increase the degree of expansion of the nozzle in order to achieve a higher specific impulse, however, this will lead to a significant increase in the design of the nozzle block, which will reduce the weight ratio of the product.

With a decrease in the binder content of more than $1 \%$, the increase in specific impulse is less than $1 \%$, which is insignificant. However, a decrease in the binder content in the SRF formulation to a level of less than $10 \%$ 
may lead to critical changes in the operational characteristics at the stages of SRF manufacturing, product operation, etc.

The scientific novelty of the work is that for the first time a method is proposed for constructing optimal plans for multifactor experiments based on the use of the "jumping frogs" algorithm, which will make it possible to construct optimal experimental plans without completely enumerating the experimental permutation options.

The practical significance of the results of the work lies in the fact that software has been developed that implements the proposed method, as well as experiments have been carried out that have confirmed its efficiency and allow scientists to recommend it in practice when constructing optimal planning matrices for experiments.

Prospects for further research are the application of the developed software on a wider range of practical tasks.

\section{REFERENCES}

1. Bona M. Combinatorics of permutations. N.-Y., CRC Press, 2012, 478 p.

2. Berger P. D., Maurer R. E. Experimental Design with Applications in Management, Engineering and the Sciences. Celli New York, Springer, 2018, 640 p.

3. Hoskins D. S. Combinatorics and Statistical Inferecing, Applied Optimal Designs, 2007, No. 4, pp. 147-179.

4. Bailey R. A., Cameron P. G. Combinatorics of optimal designs, Surveys in Combinatorics, 2009, Vol. 365, pp. 1973.

5. Morgan J. P. Association Schemes: Designed Experiments, Algebra and Combinatorics, Journal of the American Statistical Association, 2005, Vol. 100, No. 471, pp. 1092- 1093.

6. Rodrigues M. I., Iemma A. F. Experimental Design and Process Optimization. N.-Y., CRC Press, 2016, 336 p.

7. Yakovlev S. V. Properties of combinatorial optimization problems over polyhedral-spherical sets, Cybernetics and Systems Analysis, 2018, Vol. 54, No. 1, pp. 99-109.

8. Yakovlev S. V. Convex extensions in combinatorial optimization and their, Springer Optimization and its Applications, 2017, Vol. 130, pp. 567-584.
9. Koshevoy N. D., Kostenko E. M., Pavlyk A. V. et al Research of multiple plans in multi-factor experiments with a minimum number of transitions of levels of factors, Radio Electronics, Computer Science, Control, 2019, No. 2, pp. 53-59. DOI:10.15588/1607-3274-2019-2-6

10. Halchenko Y. Ya., Trembovetska R. V., Tychkov V. V. Development of excitations structure RBF-metamodels of inoving concentriced dycurrent probe, Electrical engeneering \& electromechanics, 2019, No. 2, pp. 28-38. DOI: 10.20998/2074-272X.2019.2.05

11. Montgomery D. C. Design and Analysis of Experiments, 9th Edition. Wiley, 2017, 629 p.

12. Koshevoy N. D. Primenenie algoritma prygajushhih ljagushek dlja optimizacii po stoimostnym (vremennym) zatratam planov polnogo faktornogo jeksperimenta, Radioelektronni i komp'uterni sistemi - Radioelectronic and computer systems, 2018, No. 4, pp. 53-61. DOI: 10.32620/reks.2018.4.05

13. Koshevoy N. D. Zastosuvannja algoritmu mavpjachogo poshuku dlja optimizaciï planiv povnogo faktornogo eksperimentu, Zbirnik naukovih prac' Vijs 'kovogo institutu Kiivs'kogo Nacional'nogo universitetu imeni Tarasa Shevchenka-Collection of Scientific Papers of the Military Institute Military Institute of Taras Shevchenko National University of Kyiv, 2018, No. 61, pp. 61-69.

14. Karpenko A. P. Sovremennye algoritmy poiskovoj optimizacii. Algoritmy, vdohnovlennye prirodoj: uchebnoe posobie. Moscow, izd-vo MGTU im. N. Je. Baumana, 2014, $446 \mathrm{p}$.

15. Koshevoy N. D., Kostenko E. M., Muratov V.V. et al. Comparative analysis of optimization methods by cost (time) costs of full factor experiment plans, Radio Electronics, Computer Science, Control, 2020, No. 1, pp. 54-62. DOI: $10.15588 / 1607-3274-2020-1-6$

16. Koshevoy N. D., Kostenko E. M., Muratov V. V. Application of the fish search method for optimization plans of the full factor experiment, Radio Electronics, Computer Science, Control, 2020, No. 2, pp. 44-55. DOI: 10.15588/16073274-2020-2-5

Received 15.01.2020. Accepted 11.01.2021.

УДК 519.24

\section{ЗАСТОСУВАННЯ МЕТОДУ «СТРИБАЮЧИХ ЖАБ» ДЛЯ ДОСЛІДЖЕННЯ ТА ОПТИМІЗАЦІЇ ТЕХНОЛОГІЧНОГО ПРОЦЕСУ}

Кошовий М. Д. - д-р техн. наук, професор, завідувач кафедри інтелектуальних вимірювальних систем та інженерії якості, Національний аерокосмічний університет ім. М. Є. Жуковського «Харківський авіаційний інститут», Харків, Україна.

Муратов В. В. - аспірант кафедри інтелектуальних вимірювальних систем та інженерії якості, Національний аерокосмічний університет ім. М.Є. Жуковського «Харківський авіаційний інститут», Харків, Україна.

Кириченко О. Л. - канд. техн. наук, головний технолог, Державне Підприємство «Науково-виробниче об'єднання «Павлоградський хімічний завод», Павлоград, Україна.

Борісенко С. А. - керівник групи, Державне Підприємство «Науково-виробниче об’єднання «Павлоградський хімічний завод», Павлоград, Україна.

\section{АНОТАЦІЯ}

Актуальність. Запропоновано застосування методу «стрибаючих жаб» для побудови оптимальних планів експериментів за вартісними (часовими) витратами при дослідженні технологічних процесів та систем, що дозволяють здійснювати над ними активний експеримент. 
Об’єкт. Методи оптимізації за вартісними (часовими) витратами, основані на застосуванні алгоритму пошуку «стрибаючих жаб».

Метою роботи $є$ отримання результатів оптимізації шляхом оптимізації за допомогою алгоритму «стрибаючих жаб» за вартісними (часовими) витратами планів повного факторного експерименту.

Метод. Запропоновано метод побудови за вартісними (часовими) витратами реалізації матриці планування експерименту з використанням алгоритму «стрибаючих жаб». На початку вводиться кількість факторів і вартість переходів для кожного рівня факторів. Потім з урахуванням введених даних формується початкова матриця планування експерименту. Метод «стрибаючих жаб» визначає найбільш «успішну жабу» та найменшу вартість переходів між рівнями для кожного 3 факторів. Після цього виконуються перестановки «жаб». «Жаба» прагне до найбільш «успішних» і, за умови, що вона залишається поруч, залишається на місці. Також розраховується виграш порівняно 3 початковою вартістю (часом) експерименту.

Результати. Розроблено програмне забезпечення, що реалізує запропонований метод, який використовувався для проведення обчислювальних експериментів для вивчення властивостей цих методів при вивченні технологічних процесів і систем, що дозволяють здійснювати над ними активний експеримент. Отримані результати оптимальних планів експериментів за вартісними (часовими) витратами порівнюються 3 початковою вартістю експерименту та розраховується виграш у порівнянні з початковим планом експерименту.

Висновки. Проведені експерименти підтвердили працездатність запропонованого методу та програмного забезпечення, яке його реалізує, а також дозволяє рекомендувати його для практичного використання при побудові оптимальних матриць планування експериментів.

КЛЮЧОВІ СЛОВА: оптимальний план, алгоритм «стрибаючих жаб», оптимізація, планування експерименту, вартість, виграш.

УДК 519.24

\section{ПРИМЕНЕНИЕ МЕТОДА «ПРЫГАЮЩИХ ЛЯГУШЕК» ДЛЯ ИССЛЕДОВАНИЯ И ОПТИМИЗАЦИИ ТЕХНОЛОГИЧЕСКОГО ПРОЦЕССА}

Кошевой Н. Д. - д-р техн. наук, профессор, заведующий кафедрой интеллектуальных измерительных систем и инженерии качества, Национальный аэрокосмический университет им. Н. Е. Жуковского «Харьковский авиационный институт», Харьков, Украина.

Муратов В. В. - аспирант кафедры интеллектуальных измерительных систем и инженерии качества, Национальный аэрокосмический университет им. Н.Е. Жуковского «Харьковский авиационный институт», Харьков, Украина.

Кириченко А. Л. - канд. техн. наук, главный технолог, Государственное предприятие «Научно-производственное объединение «Павлоградский химический завод», Павлоград, Украина.

Борисенко С. А. - руководитель группы, Государственное предприятие «Научно-производственное объединение «Павлоградский химический завод », Павлоград, Украина.

\section{АННОТАЦИЯ}

Актуальность. Предложено применение метода «прыгающих лягушек» для построения оптимальных планов экспериментов по стоимостным (временными) затратами при исследовании технологических процессов и систем, позволяющих осуществлять над ними активный эксперимент.

Объект. Методы оптимизации по стоимостным (временным) затратам, основанные на применении алгоритма поиска «прыгающих лягушек».

Целью работы является получение результатов оптимизации путем оптимизации с помощью алгоритма поиска «прыгающих лягушек» по стоимостным (временными) затратами планов полного факторного эксперимента.

Метод. Предложен метод построения по стоимостным (временными) затратами реализации матрицы планирования эксперимента с использованием алгоритма «прыгающих лягушек». В начале вводится количество факторов и стоимость переходов для каждого уровня факторов. Затем с учетом введенных данных формируется начальная матрица планирования эксперимента. Метод «прыгающих лягушек» определяет «успешную лягушку» по наименьшей стоимости переходов между уровнями по каждому из факторов. После этого выполняются перестановки «лягушек». «Лягушка» стремится к наиболее «успешной» и, при условии, что находится рядом, остается на месте. Также рассчитывается выигрыш по сравнению с начальной стоимостью (времени) эксперимента.

Результаты. Разработано программное обеспечение, реализующее предложенный метод, который использовался для проведения вычислительных экспериментов для изучения свойств этих методов при изучении технологических процессов и систем, позволяющих осуществлять над ними активный эксперимент. Полученные результаты оптимальных планов экспериментов по стоимостным (временными) затратами сравниваются с начальной стоимостью эксперимента и рассчитывается выигрыш по сравнению с первоначальным планом эксперимента.

Выводы. Проведенные эксперименты подтвердили работоспособность предложенного метода и программного обеспечения, которое его реализует, а также позволяет рекомендовать его для практического использования при построении оптимальных матриц планирования экспериментов.

КЛЮЧЕВЫЕ СЛОВА: оптимальный план, алгоритм «прыгающих лягушек», оптимизация, планирование эксперимента, стоимость, выигрыш. 


\section{ЛІТЕРАТУРА / ЛИТЕРАТУРА}

1. Bona M. Combinatorics of permutations / M. Bona. - N. -Y : CRC Press, 2012. -478 p.

2. Berger P. D. Experimental Design with Applications in Management, Engineering and the Sciences / P. D. Berger, R. E. Maurer. - Celli New York : Springer, 2018. - 640 p.

3. Hoskins D. S. Combinatorics and Statistical Inferecing / D. S. Hoskins // Applied Optimal Designs. - 2007. - № 4. - P. 147-179.

4. Bailey R. A. Combinatorics of optimal designs / R. A. Bailey, P. G. Cameron // Surveys in Combinatorics. - 2009. Vol. 365. - P. 19-73.

5. Morgan J. P. Association Schemes: Designed Experiments, Algebra and Combinatorics / J. P. Morgan // Journal of the American Statistical Association. - 2005. - Vol. 100, № 471. - P. 1092-1093.

6. Rodrigues M. I. Experimental Design and Process Optimization / M. I. Rodrigues, A. F. Iemma. - N.-Y. : CRC Press, 2016. - 336 p.

7. Yakovlev S. V. Properties of combinatorial optimization problems over polyhedral-spherical sets / S. V. Yakovlev, O. S. Pichugina // Cybernetics and Systems Analysis. 2018. - Vol. 54, № 1. - P. 99-109.

8. Yakovlev S. V. Convex extensions in combinatorial optimization and their / V. S. Yakovlev // Springer Optimization and its Applications. - 2017. - Vol. 130. - P. 567-584.

9. Research of multiple plans in multi-factor experiments with a minimum number of transitions of levels of factors $/$ N. D. Koshevoy, E. M. Kostenko, A. V. Pavlyk et al. // Radio Electronics, Computer Science, Control. - 2019. № 2. - P. 53-59. DOI:10.15588/1607-3274-2019-2-6
10. Halchenko Y. Ya. Development of excitations structure RBF-metamodels of inoving concentriced dycurrent probe / Y. Ya. Halchenko, R. V. Trembovetska, V. V. Tychkov // Electrical engeneering \& electromechanics. - 2019. - № 2. P. 28-38. DOI: 10.20998/2074-272X.2019.2.05.

11. Montgomery D. C. Design and Analysis of Experiments, 9th Edition / D. C. Montgomery. - Wiley, 2017. - 629 p.

12. Кошевой Н. Д. Применение алгоритма прыгающих лягушек для оптимизации по (временным) затратам полного факторного эксперимента / Н. Д. Кошевой, В.В. Муратов // Радиоэлектронные и компьютерные системы. - 2018. - № 4. - P. 53-61. DOI: 10.32620/reks.2018.4.05

13. Кошевой Н. Д. Застосування алгоритму мавпячого пошуку для оптимізації планів повного факторного експерименту / Н. Д. Кошевой, В. В. Муратов // Збірник наукових праць військового інституту Київського Національного імені Тараса Шевченка. - 2018. - № 61. - Р. 6169 .

14. Карпенко А. П. Современные алгоритмы поисковой оптимизации. Алгоритмы, вдохновленные природой : учебное пособие / А. П. Карпенко. - М. : Изд-во МГТУ им. Н. Э. Баумана, 2014. - 446 с.

15. Koshevoy N. D. Comparative analysis of optimization methods by cost (time) costs of full factor experiment plans / N. D. Koshevoy, E. M. Kostenko, V. V Muratov et al. // Radio Electronics, Computer Science, Control. - 2020. № 1. - P. 54-62. DOI: 10.15588/1607-3274-2020-1-6

16. Koshevoy N. D. Application of the fish search method for optimization plans of the full factor experiment / N. D. Koshevoy, E. M. Kostenko, V. V. Muratov // Radio Electronics, Computer Science, Control. - 2020. - № 2. - P. 44-55. DOI: $10.15588 / 1607-3274-2020-2-5$ 